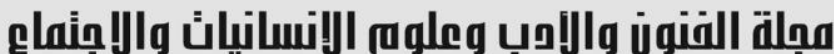 \\ Journal of Arts, Literature, Humanities and Social Sciences www.jalhss.com \\ Volume (69) July 2021 \\ 2021 بوليو \\ العدد (69)

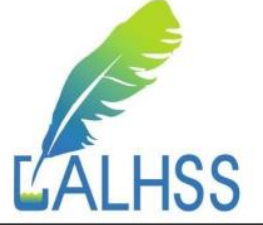 \\ Attitudes of University Students in Kurdistan region of Iraq towards Different Methods of Evaluation (A Study in Educational Sociology)
}

\author{
Assist. Prof. Dr.Miran Mohammad Salih \\ Faculty of Education, Soran University-Iraq \\ Email: meeran.salih@kue.soran.edu.iq \\ Zina Adil Ismail Chaqmaqchee \\ Faculty of Education, Soran university- Iraq \\ Email: Zina.ismail@soran.edu.iq
}

\begin{abstract}
Learning in higher education can be achieved from students' engagement in peer, group and their own learning, learning through assessment can be a process in which learners reflect and judge on their own works either in peers, group or individually however, Assessment develop students understanding of learning objectives and success criteria. Students are motivated and engaged when they work together and reflect each other's work critically. The aim of the study was to investigated students' attitudes towards different methods of evaluation, that is group evaluation, peer evaluation, and self-assessment. The study was conducted with first-year, undergraduate students in Kurdistan universities which applying the bologna process in their systems. The sample confirmed 324 students from different universities and departments in the Iraqi Kurdistan region. The study was dependent on the scale prepared by the researchers to measure the attitudes of the students. To analyses the data, the statistical package of social science (SPSS) was applied. The results revealed that overall of the students feels satisfactory with self-assessment more than with peer and group assessment. Although, some students come across obstacles of assessing their works, they preferred self-assessment. and all types of assessment are essential in an academic learning process. These results indicate that the students have positive attitudes towards self-evaluation more than teacher or peer and group evaluation. At the end of the study, the researchers presented a set of recommendations and suggestions.
\end{abstract}

Keywords: Assessment, group, self and peer assessment, Evaluation, higher education. 


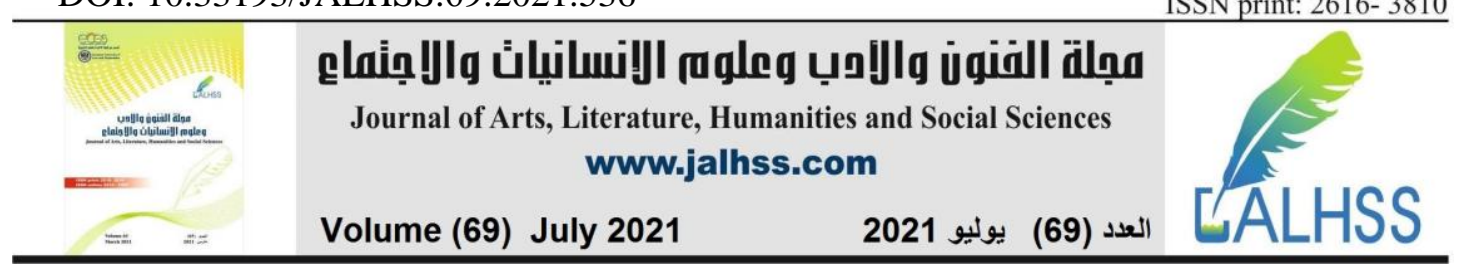

Introduction:

The pedagogy of assessment for constructive learning has arisen in the west first, then the system of education in the Middle East started to apply them. Traditionally, academic staff was focused on the assessment by grading and little emphasis on the assessment by learners. It should involve students as active learners to obtain the best outcome results. Cognitive and reflective skills are the main role in the process of learning ( $\mathrm{Lu} \&$ law, 2012). The potential of group, peer, and selfassessment to support student's achievement in learning has been focused on learning and practice. In the past, academic staffs assess student's work by themselves. It's time to shift from teacher's assessment into colleague's assessment together; the students can inquire about the teacher's help in case they need it. In Iraqi Kurdistan, we need to alter the traditional pedagogical system into the group, peer, and selfassessment. It consolidates students' learning also promotes reflective thinking skills, self-confidence and responsibility. Initially, the students challenge to adapt new pedagogy of assessment, but they will adjust the model of education in their system (Bryant \& Carless, 2009).

Educationalist confirms that assessment is central to student's experience and learning which broaden their horizon. Assessment is about students grading, judgment, supporting and achievement. Some assessment is contrived in higher education to be during the process like group, peer and self-assessment, and summative assessment. Assessment assignment is considered group working that is during the process of learning while tasks that are required results contribute summative assessment as to its focused on the final product (Hernández, 2012). A study by researchers conducted that assessment of "General education is a place of convergence for students and faculty, outside of academic departments and majors, and represents an opportunity for focusing on learning and student experiences that isn't found elsewhere in the institution." (Reitenauer \& Carpenter,2019).

This sort of assessment is essential for the universities but it is a complex process for the student's learning especially in Iraq. A study by the researchers posits that one of the purposes of assessment collaboration is to measure student's performance as they work and learn from each other. Collaborative learning increases students learning outcomes and skills such as social skills and their perspectives to their colleagues. It can be an integral part in students learning process; there are students who feel shy to express their attitudes towards other learners so group learning assessment can be the wider implication of the learner's outcome however students can learn collaborative work through assessment. (Webb et al., 1998).

The term "Assessment "and "evaluation" are both used in educational sectors, in the UK the term assessment is used to refer to the judgment of a student's work while evaluation is referred to the judgment regarding the courses (Taras, 2005, p. 466). Assessment in higher education focused on future learning which enhances short and long -term outcomes by assisting the students to judge their learning process. Group, peer, and self-assessment increase students' intellectual skills, so responsibility and decision are playing an essential role in the circle of learning. Students can regulate their own learning; they can reflect on their own work either individually or in peers or groups rather than relying on the teacher (Thomas et al., 


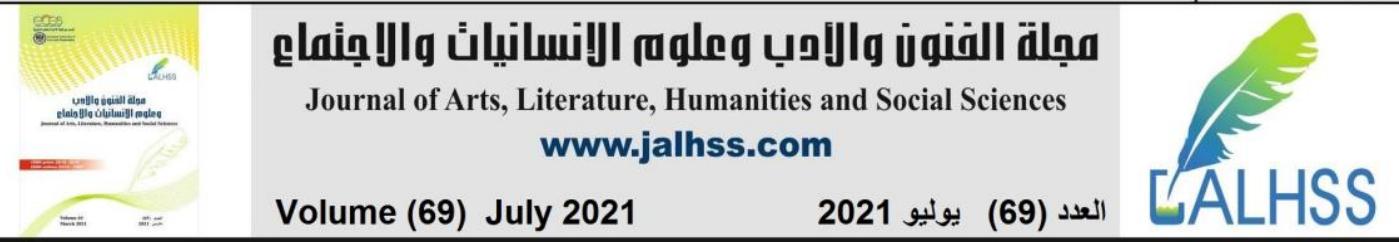

2011). Self-assessment enhances student's confidence in their ability to do and solve their issues regarding their works and become more dependent in their learning process. There is a distinction between a student's self-assessment and self-evaluation. Students' self-assessment can determine the sorts of errors made in their works while student self-evaluation is about their reflections of their general understanding of the subject (Virginia \& Carol, 1996).

Group, self, and peer assessment are a means of deeper learning in the education cycle. Assessment and grades are linked to each other however the cultural education plays a vital role in student's progress. In some colleges and universities, the approach is a more likely teacher-Centre role that is the learners depended on the teacher's assessment only. This issue returns back to cultural education progress. Group, self, and peer assessment are against cultural norms and it should yield a reasonable outcome for students learning process in the educational curriculum. These sorts of assessments have a deep-seated place in academic learning today and in the future (Diana, 2008). In activities group, peer and self, students were engaging with standards and criteria. The students judge their own works individually, they work with peers and in groups to exchange their skills and benefit from each other in learning. They can experience new skills regarding their subjects and it's a cycle to gather different standards of learners to assess their works positively (Nancy \& Judy, 2000). The development of group, peer, and self-evaluation plays an integral part in the universities in higher education as it increases student's awareness towards the process of evaluation and constructive skills however the use of marking criteria and standards in their works (Gamze \& Howard, 2009).

\section{Research Questions:}

1.What is the nature of the attitudes of the students to ward three types of evaluation (self-evaluation, peer evaluation and group evaluation)?

2.What is the most common type of evaluation prefer by students?

3.Is there any significant difference in the students' attitudes toward type of evaluation according to gender variable?

4.Does the students' attitudes toward type of evaluation vary according to the university variable?

\section{Literature review}

Assessment is a task among the students to achieve the main goal for purposes of learning. Assessment is like a spur among the learners to negotiate and exchange ideas to gain the learning outcomes, especially the students who challenge the difficulty of learning individually or in groups (Espasa et al., 2018). Nevertheless "Assessment should focus on performance, not the person." (Donald, 1987, p.565) Group, self, and peer assessment have become widely used in 21-century academic development especially in the university curricula in higher education. The curriculum develops communication and decision making, effectiveness, attitudes, excitement, energy, and courage for the students. When the learners get bored from the lecture or challenging problem solving, they can create an atmosphere to exchange ideas with the participants to gain new thinking skills. Hence working together makes 


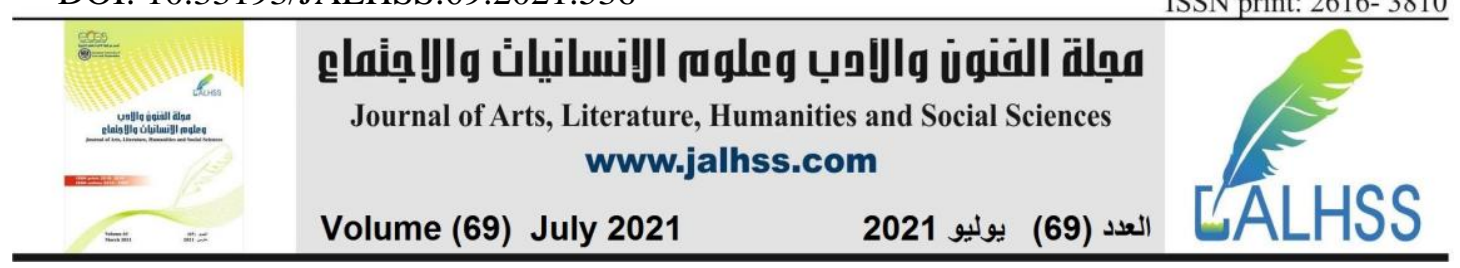

the lecture more enjoyable and facilitates learning among the students and the teachers (Issa, 2012). A study presented by the researchers stated "Internationally, higher education institutions seem to have limited success in their quest for increasing students' engagement and satisfaction with feedback" (Kim et al, 2020) however it's time to alter the phrase "me" to "we" as the researcher stated that "We are currently leaving in an era of competitive and individualistic learning. The "me" classrooms and "do your own thing" academic work are fading, and we are entering an era of interdependence and mutuality. The current trend is for "we" classrooms and "we are all in this together" (Jonson at el, 1991, p.21).

It is worth noting that peer assessment plays the role of increasing cognitive skills and interaction between student-student and teacher-student. It enables the learners to rate their peer's work easily, however it saves time and creates an outgoing atmosphere in the class as some of the students lack self-confidence. Peers can enhance the quality of learning. The students learn from each other and they learn from the teacher generally. Mostly, Peers accept criticism from their partners than the teacher (Wen \& Tsai, 2006). peer assessment creates an active and positive role for cooperation among the students to learn from each other regarding different cultures and techniques of learning skills. In peer assessment, the students are using criteria to make judgments about their peers' work to provide marks and comments regarding their works while self-assessment regarding the student's judgment of their works. This is the most difficult type of assessment; some students challenge to assess their work individually because of a lack of experience regarding learning and confidence. Sometimes student's background education is scarce to give feedback themselves or realize their mistakes on learning outcomes (Bryant \&Careless, 2009). What is important to consider in the teaching and learning process is that students learn from their colleagues, most pieces of evidence demonstrated that "What is the most effective method of teaching? Is that it depends on the goal, the students, the content, and the teacher. But the next best answer is, Students, teaching other students." So peer teaching is effective for students learning outcomes (McKeachie et al. 1986, p. $63)$.

Peer assessment was manipulated to assess student's product, presentation, communication skills, and performances. It is evident that peer assessment was mostly applied by assessing student's communication skills and presentation that has been provided by the teachers to assess their works (Gulsen \& Mehtap, 2007). As though peer interaction can be stimulating by metacognition. Peer interaction help learners to reflect their learning process and justifying their decision, ideas individually or in peers (Minjeong \& Teeheon, 2013). Peer assessment connotes an interest in the teaching and learning approach. Peer assessment increased in higher education in recent years. It is focused on construction rather than knowledge. It helps the learners to enhance their understanding, learning and reflection in different sectors. Sometimes students are reluctant to assess their peer's work, so peer assessment enhances their capability to reflect critically. The students learn from each other when they assess their works together. It enhances their metacognitive skill that is they will be able to solve problems in a professional way (Olliver \& Amanda, 2013). 


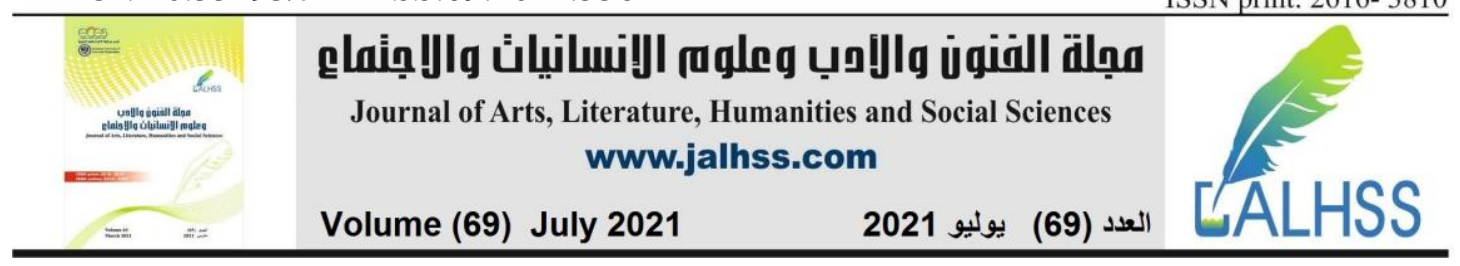

However, Student's engaging with assessments is essential for learning and the educational process. It yields students an active role and responsibility towards learning. They can perceive peer assessment as a tool for achievement and improvement. It's essential to learn how to assess their works individually then it will be easier to judge and assess others' ideas. Student's assessments should be handled with the utmost care because assessment needs professional people to achieve certain purposes of education. Sometimes students challenge to assess their peers' work due to inferior level. Peer assessment contributes enhancement and achievement of the learning process, it helps them to resolve an assignment by applying assessment so it enables them to collaborate and exchange their ideas about the task. Positive education and environment yield confidence and professionalism among the learners (Tatjana, 2014). Another researcher resorts to peer assessment to assess students' work rather than evaluating by the teacher however it reduces the teacher's workload and efforts especially in writing study (L'hadi \& Alain, 2009). Peer assessment deployed in elementary, secondary, and colleges successfully. Initially, the teachers and the students experience anxiety about the process. The teacher should encourage the learners positively about the evaluation process however promoting self-esteem, responsibility, and motivation among the assessors. It's essential for both assessors and assesses (Keith, 2009).

In order to broaden student's horizons with the best approach and fulfilling a reliable curriculum, it's essential to build up communication and satisfaction among the students. This can be achieved by a group working to transfer and gain skills among each other. The learners can learn from each other especially when there is a case study which is critical thinking. They can find out the solution easily by cooperating with the teams. However, conducting group activities in higher education facilitate students learning. Presentation, debate, discussion, and projects were a quest for the learner's achievement particularly works assessment. So group working becomes a prime for learning and teaching approach in higher education (Elizabeth et al, 2014). According to (Wanli et al, 2015) group assessment in collaborative learning was transpired after collaboration measurement, hence using a form or rubric for assessment to measure group's performance for the final product. Constructing ideas and communication skills enhances learners critically to produce the learning outcomes. In order to create effective, supportive learning and communities of practice, it can be defined that a "group of people bound together by shared expertise and passion or joint enterprise" (Wenger \& Snyder, 2000, p.139). Furthermore, another researcher indicated that group, self, and peer assessment facilitates learning of competence and creativity. The form of peer and self-assessment can be called fairness which is more valuable than the traditional method. At first, the teachers worried about the outcomes of learner's performance but later it was obvious that the learners can assess their performance individually or in peers and groups better than traditional methods (Christine \& Damien, 1995).

A study asserts that group working and assessment are subservient to learning. There are three sorts of group working such formal, informal learning, and team study. Informal learning group demonstrates unplanned action that is provisory. The students are free to work at any time while the formal one is visa verse. The students 


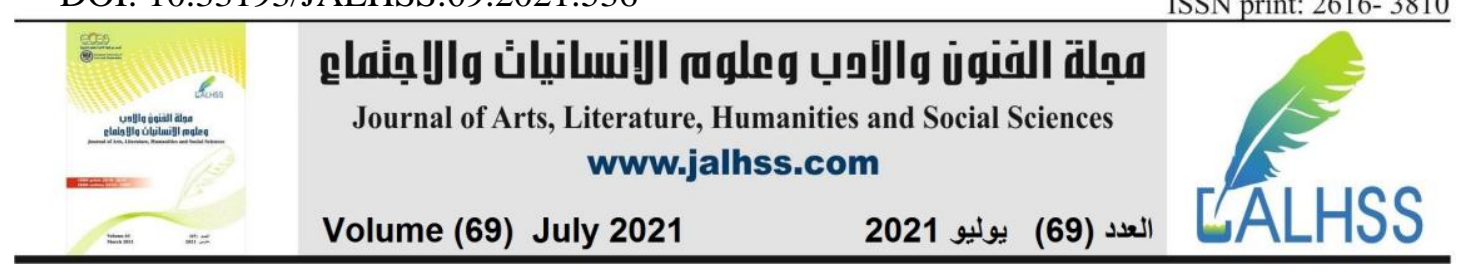

are stuck up to time; they have to complete their work at the exact time like projects, reports that last for several weeks. They can assess each other's work at an accurate time. Lastly, teamwork lasts for a semester to complete their assignments and prepare the final draft with the teams. So group working and assessment induces the students to support each other and assess mutually over a period of time (Ahmed, 2006). A researcher highlighted classroom assessment which yields students in higher-level thinking skills and being a critical thinker. Generally, it supports learning and instruction. It considers student's level of understanding and their cognitive skills among each other. The task needs individual and peer's learners to form the classroom assessment (Kemal et al., 2018).

It is evident that self-assessment is a common essay writing activity. It encourages the students to become more involved in their written work however it asserts students' smartness and responsibility towards their tasks individually. The students analyze their own performance in a creative and critical manner (Martyn \& Lynton, 1980). Many university teachers assess student's performance by judging on the student's reactions in the class. The teacher should recognize the learner's level of professionalism as there are learners that they cannot evaluate their works so they inquire the teacher for help (Peter, 1982). Following (Betty, 2007), it appeared that self-assessment is an essential part of the portfolio and authentic assessment. It comprised about reflecting on past achievement and experiences about the subject matter however evaluating thinking skills critically about the present and future plan outcomes, goals, and constrictive ideas. Students should be able to compare their works according to standards and criteria. When they try to achieve their tasks individually, they accomplish their goals successfully in relation to reality. A researcher highlighted that self-assessment is a process in which the students compare their own performances with the criteria and goals so their own works in the progress of revising. It can resemble a formative assessment. They can judge and revise their own works without relying on the teacher's evaluation (Heidi \& Anna, 2009). Some learners face difficulties in assessing their peer's work due to the inferior background of the level of students however, students prefer to work individually than communicating with other learners due to culture and misunderstanding about English language subjects.

\section{Methodology}

The methodological framework for the research and field assignments:

This study deals with the methodological framework of the research through its presentation of each chosen curriculum, and the most important field procedures that the researchers follow in their research by focusing on each of, Data collection tools and statistical methods SPSS were applied.

\section{1-Research methods}

Selecting one or several scientific approaches is essential in scientific and academic research in order to gain objective results and achieve the goals of the research (Hassan et al, 1982: 210). The research methodology means the rules and methods used in the research of social phenomena and education according to 

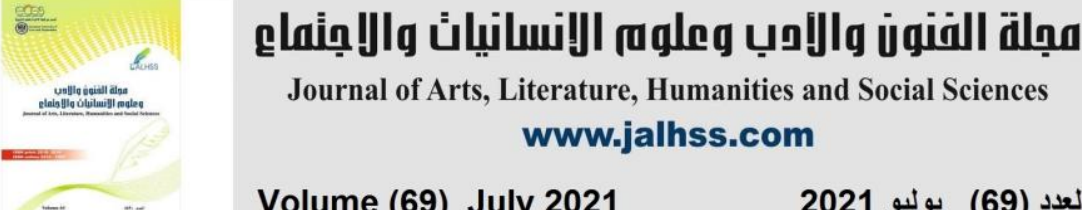

Volume (69) July 2021

يوليو 2021

(69) (69) (العدد)

scientific methods, through the stage of selecting the problem and collecting data from the field of treatment and analysis (Bailey, 1982: 215). The nature of the study and the phenomenon or problem that determines the nature of the curricula used in research and for data collection. We relied on surveying data via a questionnaire in the Kurdish language and Arabic language because the community and the sample of the research are not scientifically and correctly familiar in the English language. The questionnaire consisted of (21) items with a 5 Likert scale, it is ranging from always to very rarely. A five-point Likert responses scale was used 1 very rarely, 2 rarely, 3 sometimes, 4 much, and 5 always. After that, we translated a form and data, and in order to bring out the validity of a tool, we presented the questionnaire form for a number of experts in the specialties of educational science, psychology, sociology, educational sociology, and after deleting and modifying some paragraphs of the form, it was certified as a tool $81 \%$ On the other hand, and to find out the reliability of the form, it was distributed among 10 persons of the research sample. After 14 days, it was distributed again to the same sample, and the form reliability was (0.95). The researchers used the survey method of the sample to gain facts that is related to the students 'attitude on the group, self, and peer assessment in the universities.

\section{2-The research community:}

The research community or the frame of the sample is the original community, which includes all units or a specific sector of society. they are the individuals whom the sample chooses to search for information related to the subject of the research, we have taken the total number of the first year students in government universities in the Kurdistan region located in four governorates as their number in a academic year (2020-2019) male and female students in all departments and colleges belonging to universities who implement the Bologna system in the first year in universities and then pulled (male and female students). This research seeks to find out the position of students on the process of evaluating the group, self and peer.

\section{3-The research sample:}

The sample of students was chosen in the universities of the Kurdistan Region for the academic year (2020-2019) in order to ensure the ability of this sample to represent the community. The size of the sample was confirmed in the number of (324) according to the previous research confirmed that the greater the sample size, the lower the standard error of the survey and its ability to Community representation increased. So the sample consisted of (324) students divided by (96) male and (228) female students. In a deliberate, intentional method. It intended to take a fixed share from each category as this method provides data and information on the proportions of specific groups after classification to multiple social units (Sarantakos, 1993: 138). The tables $(1,2,3,4)$ demonstrates the Properties of the sample

Table (1) Distribution of the sample members according to the gender

\begin{tabular}{|c|c|c|}
\hline Gender & Frequency & Percent \\
\hline Male & 96 & 29.6 \\
\hline female & 228 & 70.4 \\
\hline Total & 324 & 100.0 \\
\hline
\end{tabular}




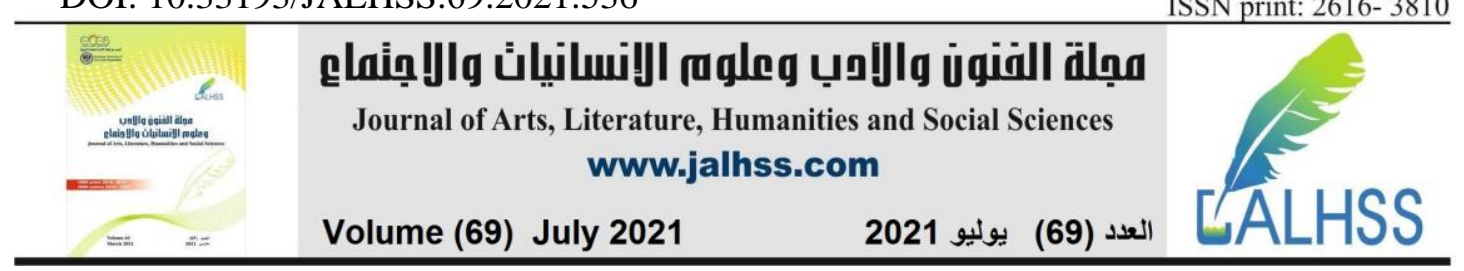

Table (2) Distribution of the sample members according to the universities

\begin{tabular}{|c|c|c|}
\hline University & Frequency & Percent \\
\hline Salahaddin & 91 & 28.1 \\
\hline Soran & 89 & 27.5 \\
\hline Duhok & 134 & 41.3 \\
\hline Koya & 2 & .6 \\
\hline Sulaymany & 8 & 2.5 \\
\hline Total & 324 & 100.0 \\
\hline
\end{tabular}

Table (3) Distribution of the sample members according to the colleges

\begin{tabular}{|c|c|c|}
\hline College & Frequency & Percent \\
\hline Education & 123 & 38.0 \\
\hline Basic education & 25 & 7.7 \\
\hline Arts & 14 & 4.3 \\
\hline Social science & 63 & 19.4 \\
\hline Medicine & 58 & 17.9 \\
\hline Language & 2 & .6 \\
\hline Management & 29 & 9.0 \\
\hline Science & 10 & 3.1 \\
\hline Total & 324 & 100.0 \\
\hline
\end{tabular}

Table (4) Distribution of the sample members according to the departments

\begin{tabular}{|c|c|c|}
\hline Department & Frequency & Percent \\
\hline English & 63 & 19.4 \\
\hline Kurdish & 33 & 10.2 \\
\hline History & 116 & 35.8 \\
\hline Kindergarten & 6 & 1.9 \\
\hline Social science & 18 & 5.6 \\
\hline Medicine & 27 & 8.3 \\
\hline Math & 16 & 4.9 \\
\hline Chemistry & 42 & 13.0 \\
\hline Administration & 1 & .3 \\
\hline Physics & 2 & .6 \\
\hline Total & 324 & 100.0 \\
\hline
\end{tabular}

\section{4-Research fields}

The identification of the research area is necessary for academic research as it reflects the reality of society and its conditions. The researchers and those interested in research agree on phenomena and social problems on the existence of three areas of research which are:

A-Spatial domain: The spatial domain and geographic region chosen to collect field information are the universities of the Kurdistan region.

B-The human field: The existence of any entity that would define a society that has its educational, social, cultural, political, economic, justification for interests and 

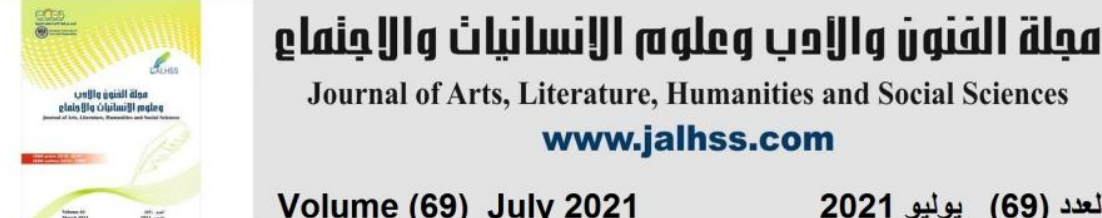

Volume (69) July 2021

يوليو 2021

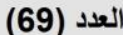

common features. the human field for our research are students of the first stages in the universities of the Kurdistan Region with scientific and human specialization.

c- Time range: means the time limit specified for research and the period during which they collect the scale forms and interviews with the sample members who were included in the research for the period (April to Jun/2020).

\section{5- Statistical methods.}

The statistical approach is an organized method that summarizes, organizes, analyzes the information, and finds the link between the characteristics of the information, the researched variables, extracting conclusions from the data, then formulating laws and setting rules from repeated observations, and gives the scientific form of research (Omar, 1996: 81), the researchers used a statistical approach Descriptive by using the SPSS program (Gouda, 2008:7).

\section{The result:}

1.To find out the nature of the trends among the sample members of university students, the data contained in the research were statistically processed by using the T-test for one sample, and the results showed a statistically significant difference between the calculated averages of the sample scores with the hypothetical mean for each of the three dimensions, and table (5) shows that.

Table (5) One-Sample Statistics for comparing between means

\begin{tabular}{|c|c|c|c|c|c|c|c|}
\hline Variable & No. & $\begin{array}{c}\text { Calculated } \\
\text { Mean }\end{array}$ & Std. & $\begin{array}{c}\text { Theoretical } \\
\text { Mean }\end{array}$ & t-value & df & Sig \\
\hline Self Evaluation & 324 & 25.617 & 7.029 & 21 & 11.823 & 323 & .001 \\
\hline Peer Evaluation & 324 & 22.947 & 7.709 & 21 & 4.547 & 323 & .001 \\
\hline Group evaluation & 324 & 27.256 & 7.438 & 21 & 15.138 & 323 & .001 \\
\hline
\end{tabular}

These results indicate that university students have generally positive attitudes towards the three types of evaluation, which It can be explained by awareness of the importance of using these different types of evaluation.

It seems that students prefer primarily the group evaluation method, as their mean scores in this method reached (27.256) score, followed in second place by their preference for the self-evaluation method with an average of (25.617) score, while the peer evaluation method came in last place with an mean of (22.947) score.

2. To find out whether there are significant differences in the students 'attitudes towards evaluation methods according to the gender variable, the researchers used the T-test for two independent samples, and the result showed the presence of significant differences between males and females in the attitudes towards evaluation methods and the differences were in favor of females in all comparisons, and the table (6) shows that.

Table (6) The Difference in attitudes toward evaluation method According to Gender 


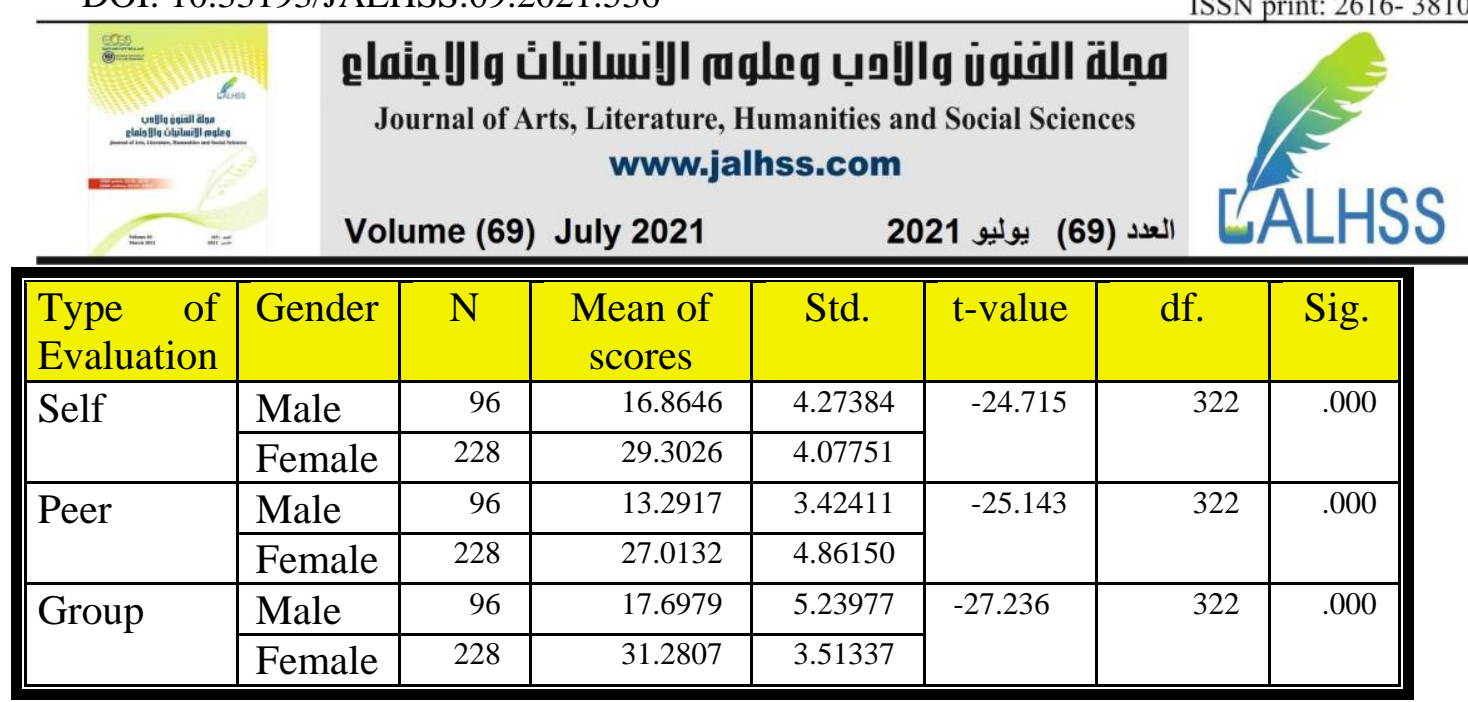

3. To find out whether there are significant differences in the students 'attitudes towards evaluation methods according to the university variable, the researchers used One-way Analyses of Variance (ANOVA). The result showed that there is a significant difference in all types of evaluation methods between the students' attitudes $s$ in the different universities and the table (7) shows that.

Table (7) The difference between Attitudes of Students according to University

\begin{tabular}{|c|c|c|c|c|c|c|}
\hline Variable & $\begin{array}{c}\text { Source of } \\
\text { Varian's }\end{array}$ & $\begin{array}{l}\text { Sum of } \\
\text { Squares }\end{array}$ & df & $\begin{array}{l}\text { Mean } \\
\text { Square }\end{array}$ & F-value & Sig. \\
\hline \multirow{3}{*}{$\begin{array}{l}\text { Self } \\
\text { evaluation }\end{array}$} & Between Groups & 12657.975 & 4 & 3164.494 & \multirow[t]{3}{*}{340.557} & \multirow[t]{3}{*}{.001} \\
\hline & Within Groups & 2954.891 & 318 & 9.292 & & \\
\hline & Total & 15612.867 & 322 & & & \\
\hline \multirow{3}{*}{$\begin{array}{c}\text { Peer } \\
\text { evaluation }\end{array}$} & Between Groups & 16427.551 & 4 & 4106.888 & \multirow[t]{3}{*}{519.188} & \multirow[t]{3}{*}{.001} \\
\hline & Within Groups & 2515.446 & 318 & 7.910 & & \\
\hline & Total & 18942.997 & 322 & & & \\
\hline \multirow{3}{*}{$\begin{array}{c}\text { Group } \\
\text { evaluation }\end{array}$} & Between Groups & 14596.251 & 4 & 3649.063 & \multirow[t]{3}{*}{404.899} & \multirow[t]{3}{*}{.001} \\
\hline & Within Groups & 2865.904 & 318 & 9.012 & & \\
\hline & Total & 17462.155 & 322 & & & \\
\hline
\end{tabular}

The existence of differences between universities in students 'attitudes towards evaluation methods can be explained by saying that universities differ in their capabilities, conditions, and educational cadres, all of which has an impact on students' attitudes.

\section{Discussion and conclusion:}

The purposes of the conducted study were to find out the students' attitude towards self, peer and group assessment for the first stage in the universities where applying bologna system in learning process. The majority of the respondents' result were positive towards Group, self-assessment and group assessment. They like assessing their performances in groups and individually more than getting help from peers. The learners can assess their performances through self-assessment, it is checking students' progress towards goals, tasks and practices. It is a way to increase learners' awareness towards their achievement and criteria. When students fulfil works individually, they can reflect and judge on their own works. Therefore, 


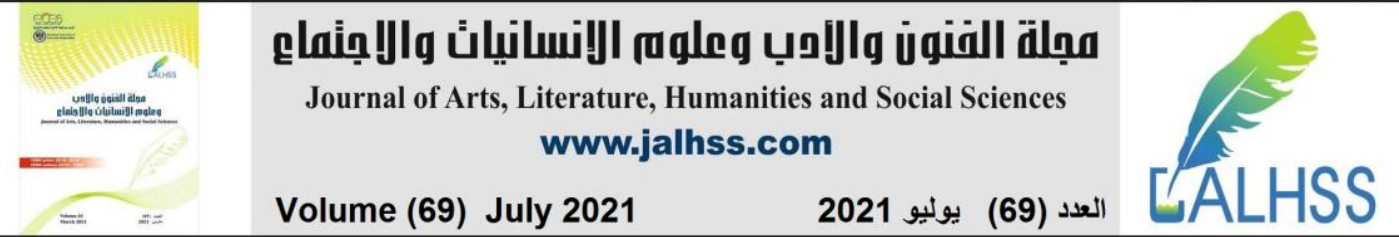

students' can enhance their performances without relying on the teacher (Andrade \& Valtcheva, 2009).

The study highlights that the results obtained from the participants who were undergraduate students (first stage), they are applying bologna process in teaching and learning system. They were from different universities in Kurdistan. Although, majority of students' attitude were positive towards self-assessment, some of them agreed with peer and group assessment. Generally, peer and group assessment is a path for student's learning, they can learn from each other and share ideas to reflect on a subject. The respondents emphasized on the usefulness of self-assessment and they somehow agreed with peer and group assessment. As some of the learner's background education is inferior so they prefer to assess their own performances individually through formative evaluation.

Although, cooperative learning guide learners to have fun and learning to how to work with each other, students of Iraqi Kurdistan region like to work individually in the university. Due to the norms, Time, living atmosphere, students cannot cooperate with each other and assess their works however, students focuses more on marks than learning (Johnson et al.,1991).

Furthermore, peer assessment seems to be valid for students of higher level background than lower level. They have better understanding regarding the criteria than the other one. Learners can judge and reflect on their colleague's draft easily (Falchikov and Goldfinch, 2000). Although, peer assessment is an opportunity for gaining new skills, students prefer to work and assess individually in the present study. In Iraqi Kurdistan, Generally, most universities were applying the system of bologna process. The system focuses on collaboration and critical thinking skills among student hence, the majority of students felt satisfactory with self-assessment. The fact that the students have motivation to work with their peers and groups but they prefer to assess their works individually. Many universities find out that selfevaluation can be a hard tool to judge and decide on their performance (Seldin,1982). Before applying bologna system, the learners used to work and assess their works individually that is why it would be difficult to communicate with the community with different cultures in the class. By the time, they get used with a new system. group and peer assessment is useful for students leaning but apparently the respondents in the present study preferred self-assessment.

During this study, some participants preferred teachers' assessment due to disability of assessing their own and peers works. Students are likely to take selfassessment in their learning process to measure their performances. It will be unsatisfactory to some academic staff, but the current study indicates student's attitude and reaction to types of assessment. To shed further light on further research for group and peer working among the students. By communicating with each other, they would have applied new skills in the process of learning in the future. 


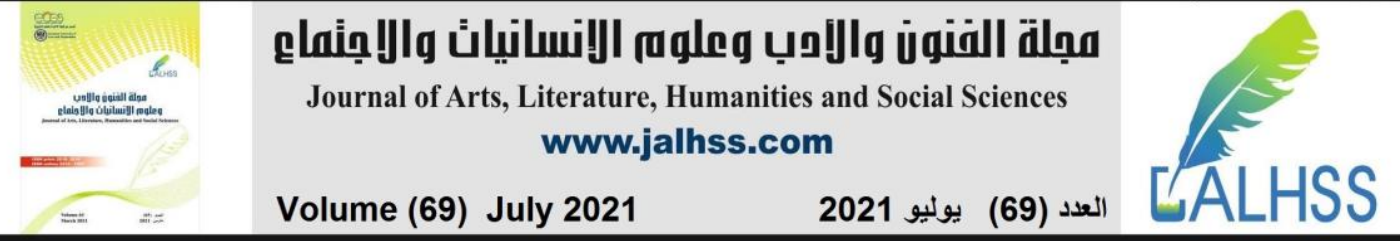

\section{References}

1-Ahmed, Hassanien (2006). Student Experience of Group Work and Group Assessment in Higher Education, Journal of Teaching in Travel \& Tourism, 6:1, 1739, DOI:10.1300/J172v06n01_02.

2-Andrade, H. and Valtcheva, A. (2009). Promoting Learning and Achievement through Self-Assessment. Theory Into Practice, Vol.48, No.1, pp.12-19. https://www.jstor.org/stable/40071571

3-Bailey, K. D. (1982). Methods of social research. New York: The free press. 4-Bell, Ch. and Keaney, D. (1995). Teaching justice? An experiment in group work and peer assessment. The Liverpool law Review. Vol. XVII (1).

5-Bryant, A., Carelss, R. (2009). Peer assessment in a test-dominated setting: empowering, boring or facilitating examination preparation? Educ Res Policy Prac, DOI 10.1007/s10671-009-9077-2.

6-Bouzidi, L. and Jaillet, A. (2009). Can online peer assessment be trusted? International Forum of Educational Technology \& Society, Vol. 12, No.4, pp. 257268. https://www.jstor.org/stable/10.2307/jeductechsoci.12.4.257

7-Densocombe, M. and Robins, L. (1980). self-assessment and essay writing. American sociological Association, vol.8, No.1, pp. 63-78. https://www.jstor.org/stable/1317048

8-Elizabeth B., Sarah D., and Brendan H. (2014). Using peer \& self-assessment for group work. 4th Annual LTSN-ICS Conference, NUI Galway, 2003 LTSN Centre for Information and Computer Sciences. www.dur.ac.uk/computer.science/SEER

9-Espasa A., Guasch T., Mayordomo R.M., Martínez-Melo M. \& Carless D. (2018). A Dialogic Feedback Index measuring key aspects of feedback processes in online learning environments. Higher Education Research \& Development, DOI:10.1080/07294360.2018.1430125.

10-Falchikov, N. and Goldfinch, J. (2000). Student Peer Assessment in Higher Education: A Meta-Analysis Comparing Peer and Teacher Marks. Review of Educational Research, Vol.70, No.3, 287-322. retrieved from https://www.jstor.org/stable/1170785

11-Gouda, M. (2008). Basic statistical analysis using (Spss), Jordan, Oman. Dar AlAwael for publication and distribution.

12-Hasan, Ihsan, Mohammad and Abdulhsein, Z. (1982). social statistic, Mosul, Book house for printing and publishing.

13-Hernandez, R. (2012). Does continuous assessment in higher education support student learning? High Educ, pp64:489-502. DOI 10.1007/s10734-012-9506-7

14-Issa, T. (2012). Promoting learning skills through teamwork assessment and self/peer evaluation in higher education. IADIS International Conference on Cognition and Exploratory Learning in Digital Age. ISBN: 978-989-8533-12-8

15-Johnson, D. W., Johnson, R. T., \& Smith, K. A. (1991). Cooperative learning: Increasing college faculty instructional productivity (ASHE-FRIC Higher Education Rep.No.4). Washington, D.C.: George Washington University, School of Education and Human Development. 


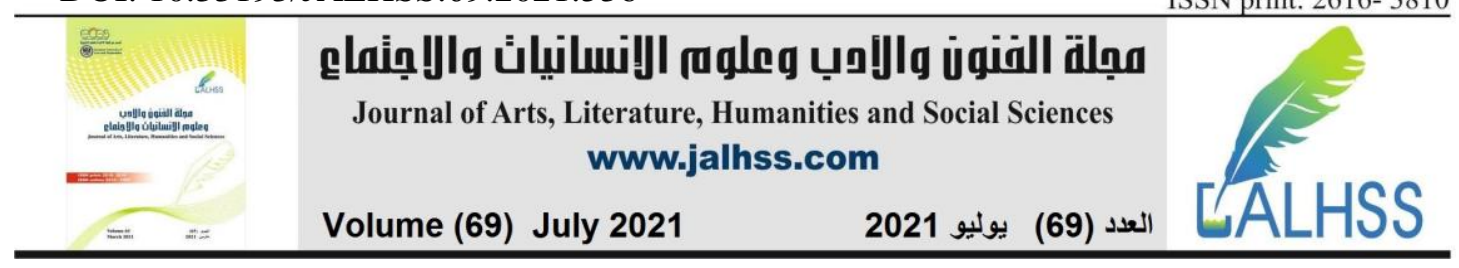

16-Johnson, David W., Roger T Johnson, and Karl A. Smith, (1991). Cooperative Learning Increasing College Faculty Instructional Productivity. ASHE-ENC Higher Education Report No. 4. Washington, D.C.: The George Washington University, School of Education and Human Development.

17-Kemal et al. (2018). Exploring Effectiveness of Classroom Assessments for Students' Learning in High School Chemistry. Research in science education, retrieved from https://doi.org/10.1007/s11165-018-9757-0

18-Kilic, G., B. and Cakan, M. (2007). Peer assessment of elementary science teaching skills. Journal of Science Teacher Education, Vol.18, No.1, pp. 91107.Springer, retrieved from https://www.jstor.org/stable/43156408

19-Kim, M. and Ryu, J. (2013). The development and implementation of a web-based formative peer assessment system for enhancing students' metacognitive awareness and performance in ill-structured tasks. Educational Technology Research and Development, Vol.61, No.4, pp. 549-561. DOl 10.1007/sl 1423-012-9266-1.

https://www.jstor.org/stable/24546653

20-Kim-Daniel Vattøy, Siv M. Gamlem \& Wenke Mork Rogne (2020). Examining students' feedback engagement and assessment experiences: a mixed study, Studies in Higher Education, DOI: 10.1080/03075079.2020.1723523.

21-Lu, J. and Law, N. (2012). Online peer assessment: effects of cognitive and affective feedback. Instructional Science, Vol.40, No.2, pp. 257-275. Retrieved from https://www.jstor.org/stable/43575413

22-Martinez, D. (2008). Reviewed Work(s): Self, Peer, and Group Assessment in ELearning by Tim S. Roberts. Society for Technical Communication, Vol.55, No.2, pp. 213-214, retrieved from https://www.jstor.org/stable/43092448

23-McKeachie, Wilbert, Paul Pintrich, Lin Yi.Guang, and David Smith. (1986). Teaching and Learning in the College Classroom: A Review of the Research Literature. Ann Arbor: Regents of the Univ. of Michigan.

24-McDonald,B. (2007). Self-assessment for understanding. The Journal of Education, Vol. 188, No. 1, pp. 25-40. Retrieved from https://www.jstor.org/stable/42744121

25-McGarr, O. and Clifford, M., A. (2013). Just enough to make you take it seriously': exploring students' attitudes towards peer assessment. Higher Education, Vol.65, No.6, pp. 677-693. DOI 10.1007/s 10734-012-9570-z., retrieved from https://www.jstor.org/stable/23481591

26-Omer, Maan, Khalil. (1996). Research methods in sociology. Oman, Shrooq house.

27-Ozogul, G. and Sullivan, H. (2009). Student Performance and Attitudes under Formative Evaluation by Teacher, Self and Peer Evaluators. Educational Technology Research and Development, Vol.57, No.3, 393-410. Retrieved from https://www.jstor.org/stable/40388636

28-Reitenauer, L., V. and Carpenter, L., R. (2018). Assessment as critical programmatic reflection. The Journal of General Education, Vol. 67, No. 3-4, pp. 226-245. Penn State University Press. Retrieved from https://www.jstor.org/stable/10.5325/jgeneeduc.67.3-4.0226 


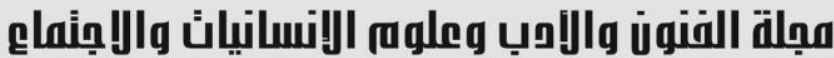 \\ Journal of Arts, Literature, Humanities and Social Sciences www.jalhss.com \\ Volume (69) July 2021 \\ العدد (69) يوليو 2021

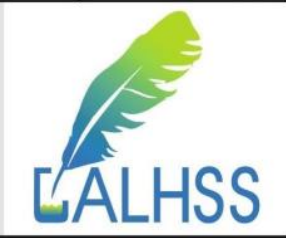

29-Sarantakos, S., S. (1993). Social Research. Macmillan press Ltd.

30-Seldin, P. (1982). Self-assessment of college teaching. Improving College and University Teaching, Vol. 30, No. 2, 70-74. Taylor \& Francis, Ltd. Retrieved from https://www.jstor.org/stable/27565488

31-Stallings, V. and Tascoine, C. (1996). student self-assessment and self- evaluation. National Council of Teachers of Mathematics, Vol. 89, No. 7, 548-554. Retrieved from https://www.jstor.org/stable/27969906

32-Tatjana, V. (2014). peer assessment as active learning method. ICOTS9, Contributed Paper - Refereed, The Netherlands: International Statistical Institute. Iase-web.org.

33-Taras, M. (2005). Assessment - summative and formative - some theoretical reflections. British Journal of Educational Studies, Vol.53, No.4, 466-478. ISSN 0007-1005.

34-Thomas, G., Martin, D. and Pleasants, K. (2011). Using self- and peer-assessment to enhance students' future-learning in higher education. Journal of University Teaching \& Learning Practice,8(1), 1-17

35-Topping, K., J. (2009). Peer assessment. Theory Into Practice, Vol. 48, No. 1,pp. 20-27.Taylor \& Francis, Ltd. DOI: 10.1080/00405840802577569. Retrieved from https://www.jstor.org/stable/40071572

36-Xing, w., Wadholm, R., Petakovic, E. and Goggins, S. (2015). Group Learning Assessment: Developing a Theory-Informed Analytics. International Forum of Educational Technology \& Society, Vol.18, No.2, pp.110-128. Retrieved from https://www.jstor.org/stable/10.2307/jeductechsoci.18.2.110

37-Webb, N. M., Nemer,K.,M., Chizhik,A.,W. and Sugrue, B. (1998). Equity Issues in Collaborative Group Assessment: Group Composition and Performance. American Educational Research Journal, Vol. 35, No.4, pp. 607-651. Retrieved from https://www.jstor.org/stable/1163461

38-Wenger, E. \& Snyder, W. M. (2000). Communities of practice: The organizational frontier. Harvard Business Review, 78 (1), 139-145.

39-Wen, L. M., Tsai, Ch. (2006). University students' perceptions of and attitudes toward (online) peer assessment. Higher Education (2006) 51: 27-44, DOI 10.1007/s10734-004-6375-8.

40-Woods, D., R. (1987). Student self - performance assessment. Journal of College Science Teaching, Vol.16, No.6, 565-568,570. https://www.jstor.org/stable/42987324 


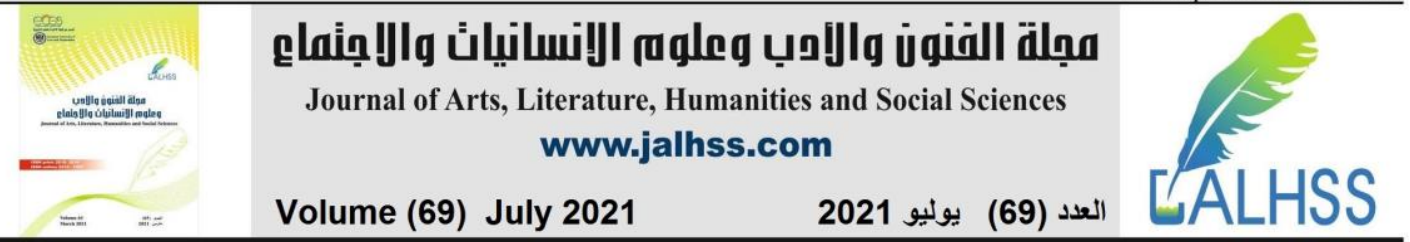

\section{Appendices}

Dear students:

The researchers conducted survey to find out about (Student's attitude towards group, peer, and self- assessment, educational-social study in universities of Kurdistan region- Iraq)

This is a survey, a tool for collecting data and information on the subject of the research. We wish this survey will get your interests however answering items accurately so that the scientific and practical benefit of this research will be realized, your answer will be anonymous and it will be used only for the purposes of scientific research. Thank you for your cooperation and interests in completing this survey. Please rate the following criteria based on your experience on-

\begin{tabular}{|c|c|c|c|c|c|c|}
\hline No & Items & 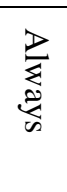 & 芯 & 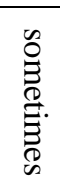 & 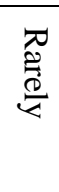 & 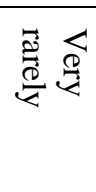 \\
\hline 1 & $\begin{array}{l}\text { Self-assessment helps me achieve goals in } \\
\text { learning. }\end{array}$ & & & & & \\
\hline 2 & Self-assessment helps me learn better in class. & & & & & \\
\hline 3 & $\begin{array}{l}\text { Self-assessment helps me judge my class } \\
\text { performance. }\end{array}$ & & & & & \\
\hline 4 & $\begin{array}{l}\text { Self-assessment depends on what I have learned } \\
\text { more than the teacher. }\end{array}$ & & & & & \\
\hline 5 & $\begin{array}{l}\text { Self-assessment reflects my skills and } \\
\text { understanding of the topic. }\end{array}$ & & & & & \\
\hline 6 & $\begin{array}{l}\text { I find difficulty to assess my work (self- } \\
\text { assessment). }\end{array}$ & & & & & \\
\hline 7 & $\begin{array}{l}\text { I prefer self-assessment more than other methods } \\
\text { of assessment. }\end{array}$ & & & & & \\
\hline 8 & $\begin{array}{l}\text { I feel comfortable when I participate in peer } \\
\text { assessment. }\end{array}$ & & & & & \\
\hline 9 & I feel happy when others assess my work. & & & & & \\
\hline 10 & $\begin{array}{l}\text { Peer assessment for my works in the class } \\
\text { contributes to my goals. }\end{array}$ & & & & & \\
\hline 11 & $\begin{array}{l}\text { I have motivation to assess the work of my } \\
\text { peers. }\end{array}$ & & & & & \\
\hline 12 & I don't like peer assessment in the classroom. & & & & & \\
\hline 13 & I have no desire to listen to peer assessment. & & & & & \\
\hline 14 & $\begin{array}{l}\text { Peer assessment for my work is an opportunity } \\
\text { to learn new skills. }\end{array}$ & & & & & \\
\hline 15 & I learn a lot through group assessment. & & & & & \\
\hline 16 & $\begin{array}{l}\text { I prefer group assessment more than other } \\
\text { methods for assessment. }\end{array}$ & & & & & \\
\hline
\end{tabular}




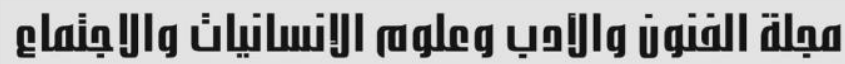 www.jalhss.com}

Journal of Arts, Literature, Humanities and Social Sciences

$=\quad$ Volume (69) July 2021

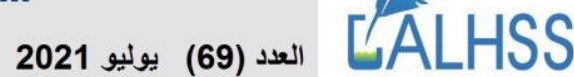

\begin{tabular}{|c|l|l|l|l|l|}
\hline 17 & $\begin{array}{l}\text { I prefer group assessment for tasks presented by } \\
\text { the teacher in the classroom. }\end{array}$ & & & & \\
\hline 18 & $\begin{array}{l}\text { Group assessment contributes to improving the } \\
\text { level of students learning. }\end{array}$ & & & & \\
\hline 19 & $\begin{array}{l}\text { I like group assessment because the students } \\
\text { express different opinions. }\end{array}$ & & & & \\
\hline 20 & $\begin{array}{l}\text { I prefer group assessment because it reflects } \\
\text { divergent (different) views. }\end{array}$ & & & & \\
\hline 21 & $\begin{array}{l}\text { I feel happy when I participate with others in } \\
\text { group assessment. }\end{array}$ & & & & \\
\hline
\end{tabular}

